\title{
Economic Mix from the Convergence and Divergence among Capitalism Economics System, Institutionalism Economics Concept and Cooperatives Economics Doctrine
}

\author{
Dr. Chanchai Petchprapunkul \\ Deputy Department Head, Department of Cooperatives Economics, Faculty of Economics, \\ Kasetsart University, Bangkok10900, Thailand (fecochpe@ku.ac.th)
}

\begin{abstract}
Sustainable economic development (SED) can be achieved by blending the advantages and get rid the disadvantages among capitalism economics system, institutionalism economics concept and cooperatives economics doctrine in to one economic mix. 45 economics academicians were invited to fill up the questionnaire. Respondents had agreed that to gain the SED, economic policy maker has to converge the "economics efficiency" from capitalism economics system, "economics responsibility" from institutionalism economics concepts and "economics distribution" from cooperatives economics doctrine into one economic mix.

Index Terms - Economic mix, capitalism economics, institutionalism economics, cooperatives economics, convergence, divergence, full Keynesian macroeconomic model
\end{abstract}

\section{Introduction}

239 years of economic management from 1776 to 2015, many economists and economic policy-maker had sometime walked away, many times miss the road. These problems are come from the strength and weakness of each of the economic concepts and how the adoption and application of each of the economics system into practices was employed.

The arguments were that: what is the real meaning of "Invisible hand" of "Adam Smith"? It is not only price mechanism, but also the social or mutual economic surplus. What when where why and how to use the "Demand management" of Keynesian as efficient as possible without the side effect from monetary and capital market? What does the Cooperatives economics doctrine had contributed to our society? What is the signaling from "Traditional Institutional Economics theories" of many great economists before Keynes and since Keynes [1] who had told us, but we don't pay attention on them, such as Common John Roger (1862-1945); Veblen, Thorstein Bunde (1857-1929); Mitchell Wesley Clair (1874-1948) and J.M. Clark. What are the suggestion proposed by Elinor Ostrom (1933-2012) and Oliver E. Williamson (1932- ) given to us last eight years on 2009?

This paper has two objectives. One is to elaborate advantages and disadvantages of capitalism economics system, cooperatives economics system and institutional economics system, the other is to examine how to blend the advantage of these three economic systems into one economic mix.

\section{Literature Review}

Capitalism economics concepts were used to be the economic management tools and mechanisms from 1776 up to present. While there are many economic phenomena shown that the capitalism economic system had some flaws or errors but most of the mainstream economists had ignored the opposite view points of them. Mostly they stick on the three concepts of "absolute advantage", "specialization", and "invisible hand", and come up with the "maximizing profit". Indeed, these three concepts should be used to demonstrate how self-interest guides the most efficient use of resources. Capitalism had created many consequences or negative effects, such as worse environment, global warming, natural disaster, over consumption of natural and economic resources. While the cooperatives economics and institutional economics can fill up these all weakness, but it was less of attentions by economists.

\section{A. Capitalism Economics}

Three prominent schools of thoughts composed together to be the bone of the economics discipline were: Classical school, Neo-classical schools and Keynesian school. The two prominent economists in the classical school were: Adam Smith and David Ricardo, the two prominent economists in the Neo-classical school were Alfred Marshall and Sir John Hick. The most famous in the Keynesian school is John Maynard Keynes.

\section{1) Classical Schools}

Adam Smith (1723-1790): is the first scholar who proposed the concept of the "Absolute Advantages" in 1776 in his second book "An Inquiry into the Nature and Causes of the Wealth of Nations". This book suggests the ways to create the richness to every country.

Indeed, in 1759, Adam Smith had ever written his first book, the "Theory of Moral Sentiments". This book was overlook by most economists. It was about those standards of ethical conduct that hold society together. But nobody pay attention to this book. Up to 1798 , before he dies, he had burnt out all of the texts or books he had wrote for many years, totally more than 16 volumes [2]. The Moral Sentiment is one of the books he had burnt out. This had created many disadvantages to people and constructs some weak points to the economics discipline. Most of people had turn from collectivism to individualism.

David Ricardo (1772-1823): was admired as the founder of a new rigorous science of political economy. He had proposed three eminent works: the first one is in 1799 when he 
had read a copy of Adam Smith's Wealth of Nations. Ten years later he had produce "The High Price of Bullion: A Proof of the Depreciation of Bank Notes (1810)". Ricardo proposed that the current inflation was due to the Bank of England's failure to restrict the issue of bank notes.

In 1815, Ricardo published the "Influence of a Low Price of Corn on the Profit of Stock". He proposed the law of diminishing returns to increments of capital and labor applied to acres of land. This study had result a concept of diminishing return from the trade off between land and labor, iron law of wage, and trade off between the employer and employee. In 1817 he proposed the Principles of Political Economy and Taxation. This study suggests the comparative cost and the "comparative advantage" between country to country, finally lead to the free trade doctrine.

2) Neoclassical schools

Alfred Marshall (1842-1924): is the economist who proposed the concept "price is always determined by demand and supply". He adopted a decreasing function to represent the demand curve and the increasing function to represent the supply curve. He is the first person to propose the static equilibrium theory by using supply and demand schedule. His second famous work is the marginal and utility theory. The third is the consumer surplus and producer surplus.

Sir John Hick (1904-1989): is the economist who elaborates the indifference curve, which used to explain the concept of standard marginal utility theory of consumer behavior with a new indifference theory, IS-LM model to explain the equilibrium of both product and financial market, and the Elasticity of substitution together with the relative income share of labor and capital.

3) Keynesian (1883-1946): Demand management

Due to the great depression in the USA and Western Europe in 1929, John Maynard Keynes had proposed the idea of demand management (1936) to the president Roosevelt. Keynes suggests that government have to inject government expenditure into the economy by using their fiscal policy or monetary policy to encourage aggregate demand level.

Keynesian demand management is appropriate for the situation during economic great depression but if the expansion fiscal policy was used too long to lift the overall economy. The economy will tends to occur an excess demand for consumption in the product market, excess demand for money in the financial market, and even excess demand for import and export in the external sector. The error in those three markets in the economy will create risk and variation to the over all economy, as elaborate in Figure 1.

In the demand side, there are three models: the first is so called the Keynesian Cross model, the second is so called financial market model, the third is so called the IS-LM model.

In the supply side, they are the sixth model or production function, and the seventh model is so called the labor market model.

Between the demand side and supply side there are other two specific models, the fourth model or GDP or AD-AS model, and the connector model between demand side and supply side (the fifth model). All the seven models are explained as the following:

The first model: Keynesian Cross Model

This model explains phenomena in the product market. Table 1 indicates GDP equation or income determination model (Y) which consists of demand side and supply side. Aggregate demand consists of four parts: consumer consumption (C), business investment (I), government expenditure $(\mathrm{G})$, and external sector (X-M). Aggregate supply also consists of four parts: Consumer consumption (C), saving of the economy $(\mathrm{S})$, government tax revenue collected from economy (T), and transfer payment of external sector (Trf).

Table 1: GDP model

\begin{tabular}{|c|c|c|}
\hline Demand side $(\mathrm{AD})$ & GDP (Income) & Supply side (AS) \\
\hline $\mathrm{AD}=\mathrm{C}+\mathrm{I}+\mathrm{G}+(\mathrm{X}-\mathrm{M})$ & $\equiv \mathrm{Y} \equiv$ & $\mathrm{C}+\mathrm{S}+\mathrm{T}+\mathrm{Trf}=\mathrm{AS}$ \\
\hline
\end{tabular}

The second model: Financial Market Model

This model explain what that happen in the financial market of the economy both monetary and capital market. Money demand (MD) of people in the economy will equal to the money supply (MS) of the economy. MD consists of two parts: Transaction demand for money (Tr), and Speculative demand for money (Sp). If MD is excess the MS, the interest rate will adjust itself by increasing. The higher interest rate will force the level of consumption and investment of private sector to decrease continuously. The excess demand in the market will adjust itself to go downward to a suitable point or turn to equilibrium. If $\mathrm{Tr}$ is increased, $\mathrm{Sp}$ will be decreased to substitute the increases in $\mathrm{Tr}$.

The third model: IS-LM Model

This model explains the equilibrium between product market and financial market in the same time. I-S is Investment-Saving, it explicit a coordinate that represent the interest rate and income level that identify equilibrium in the product market. When aggregate demand increased, the I-S model will shift rightward. L-M is Liquidity-Money, it explicit a coordinate that represent the interest rate and income level that identify the equilibrium in the financial market. At any points of time in the economy, it will be a consistency level of interest rate and income level that force the product market and financial market adjusted in to the equilibrium.

In this study, L-M model does not shift, because the movement of the economy was originally come from product market. At any points of time, if I-S and L-M model were come together, it means that such level of interest rate and income level had led both product market and financial market to come into the same equilibrium at the same point of time.

The fourth model: $A D-A S$ Model

This model explicit that after the adjustment in the three market economy, the result of the economy will then posited by aggregate demand and aggregate supply model of the economy.

The fifth model: the connector model 
This model is the connection model to connect the demand side and supply side of the economy.

The sixth model: Production Function Model

This model illustrates production function of producer. When cost of production had increased due to the higher interest rate, firm struggle from finding their source of fund, the number of firm or the level of production will then decreased and firm can not take advantage of the economy of scale and economy of scope. In the opposite way, if the cost of production is decreased, firm will then increase their production.

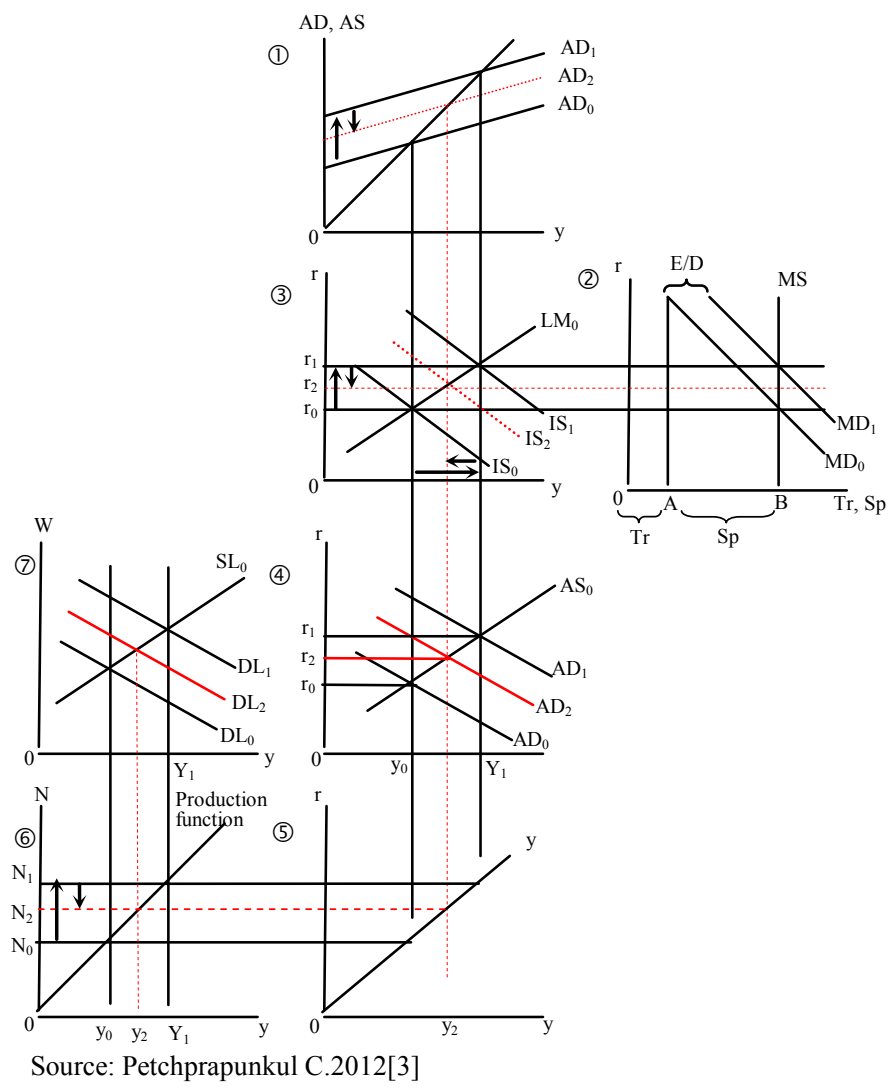

Figure 1: Full Keynesian Cross Model

The seventh model: Labor Market Model

This model explicitly indicates the wage paid to the labor and employment levels in the labor market. We can see that when aggregate demand was increased in the demand side of the product market, firms tend to require higher employment. The demand for labor tends to increased from DL0 to DL1 at the supply of labor at SL0. The wage and salary level paid to labor also increased from W0 to W1, as in model 7 of Figure 1.

The macroeconomics iterations and process

Apart from supply side, the cost of supply, oil price and any supply shock, the economic problems are always come from the demand side. Problem is that the four portions of the demand compose together to be the total aggregate demand expenditure of the economy or the GDP or the income of the nation, and it should be equal to the level of aggregate supply in the supply side of the economy.
From model 1, which represent the product market, in demand side, suppose there was an increase in the demand for consumption of people, or increase in the demand for investment of business firm, the aggregate demand will then increased from $\mathrm{AD} 0$ to $\mathrm{AD} 1$ and income will tend to increase from Y0 to Y1. The increased in aggregate demand had exceed the aggregate supply level which mostly constant, we say that the excess demand for goods and service had occurred in the demand side of the product market of the economy.

In the supply side, change in the supply of labor will affects the wage rate and the amount of wage the firms have to pay to hire the labor force. If the supply of labor increased, the wage will not increase but tend to decrease due to the increased of the amount of labor forces.

In the financial market, due to the increased of income in the economy, people tend to have higher demand for money for their consumption and expense which will exceed the level of money supply which mostly constant. Demand for money increased from the MD0 to MD1. Therefore, the interest rate which is the transmission mechanism will adjust itself to reduce the speculative demand for money. If the transaction demand for money increased, the speculative demand for money will be decreased. This reverse will control money velocity in the demand side equal to the supply side. The adjustment of interest rate is that the interest rate tends to increase up to the level that can reduce all the excess demand for money from MD0 to MD1, the interest rate will increase from $\mathrm{r} 0$ to $\mathrm{r} 1$. In the supply side, firms have to hire more labor and pay more wages to labor from W0 to W1, see step 2, Table 2.

In the factor market, firms tend to hire more labor, the demand for labor increased from DL0 to DL1. The rate of employment was also increased from the N0 to N1, see step 3 in Table 2.

The negative effect from the financial market had occurred. The increased in the interest rate had caused the higher cost to consumption or business, the level of investment will decreased and the aggregate demand will decreased from $\mathrm{AD} 1$ to $\mathrm{AD} 2$ and income level decreased from $\mathrm{Y} 1$ to $\mathrm{Y} 2$ see step 4 in Table 2.

Table 2: Macroeconomic process in the three market of the economy

\begin{tabular}{|c|c|c|c|}
\hline Market & Demand side & GDP & Supply side \\
\hline $\begin{array}{l}\text { Product } \\
\text { (1) }\end{array}$ & $\begin{array}{l}\Delta \mathrm{C} \uparrow, \quad \Delta \mathrm{I} \uparrow, \quad \Delta \mathrm{G} \uparrow \rightarrow \\
\Delta \mathrm{AD} \uparrow(\mathrm{AD} 0 \text { toAD1 })\end{array}$ & $\begin{array}{l}\rightarrow \Delta \mathrm{Y} \uparrow \\
(\mathrm{Y} 0 \text { toY1) }\end{array}$ & $\rightarrow \Delta \mathrm{SL}$ constant \\
\hline $\begin{array}{c}\text { Financia } \\
1 \\
(2) \\
\end{array}$ & $\begin{array}{l}\Delta \mathrm{MD} \uparrow(\mathrm{MD} 0 \text { to } \mathrm{MD} 1: \\
\Delta \mathrm{Tr} \uparrow, \Delta \mathrm{SP} \downarrow) \rightarrow \Delta \mathrm{r} \uparrow(\mathrm{r} 0 \\
\text { to } \mathrm{r} 1) \rightarrow\end{array}$ & 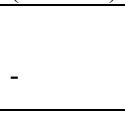 & $\begin{array}{l}\Delta \mathrm{MS} \text { constant; } \\
\Delta \mathrm{W} \uparrow(\mathrm{W} 0 \text { to } \mathrm{W} 1)\end{array}$ \\
\hline $\begin{array}{l}\text { Factor } \\
\text { (3) }\end{array}$ & $\begin{array}{l}\Delta \mathrm{DL} \uparrow \\
(\mathrm{DL} 0 \text { toDL1 }) \rightarrow\end{array}$ & - & $\begin{array}{l}\Delta \mathrm{SL} \quad \text { constant; } \\
\Delta \mathrm{N} \uparrow(\mathrm{N} 0 \text { to } \mathrm{N} 1)\end{array}$ \\
\hline Product & $\begin{array}{l}\Delta \mathrm{I} \downarrow \rightarrow \Delta \mathrm{AD} \downarrow \\
(\mathrm{AD} 1 \text { to } \mathrm{AD} 2)\end{array}$ & $\begin{array}{l}\rightarrow \Delta \mathrm{Y} \downarrow \\
\text { (Y1toY2) }\end{array}$ & $\rightarrow \Delta \mathrm{DL} \downarrow(\mathrm{DL} 1$ toDL2) \\
\hline $\begin{array}{c}\text { Financia } \\
1 \\
(5) \\
\end{array}$ & $\begin{array}{l}\Delta \mathrm{MD} \downarrow(\mathrm{MD} 1 \text { to } \mathrm{MD} 2: \\
\Delta \mathrm{Tr} \downarrow, \Delta \mathrm{SP} \uparrow) \rightarrow \Delta \mathrm{r} \downarrow(\mathrm{r} 1 \\
\text { to } \mathrm{r} 2) \rightarrow\end{array}$ & - & $\begin{array}{l}\Delta \mathrm{MS} \text { constant; } \\
\Delta \mathrm{W} \downarrow \text { (W1 to W2) }\end{array}$ \\
\hline Factor(6) & $\Delta \mathrm{DL} \downarrow$ (DL1 toDL2) $\rightarrow$ & - & $\Delta \mathrm{N} \downarrow$ (from $\mathrm{N} 1$ toN2) \\
\hline Product & $\begin{array}{l}\Delta \mathrm{I} \uparrow \rightarrow \Delta \mathrm{AD} \uparrow \\
(\mathrm{AD} 2 \text { to } \mathrm{AD} 3)\end{array}$ & $\begin{array}{l}\rightarrow \Delta \mathrm{Y} \uparrow \\
\text { (Y2toY3) }\end{array}$ & $\rightarrow \Delta \mathrm{DL} \uparrow(\mathrm{DL} 2 \mathrm{toDL} 3)$ \\
\hline
\end{tabular}


In the financial market (step 5) the decreased of income, the demand for money had reduced from MD1 to MD2, the interest rate had reduced from $\mathrm{r} 1$ to $\mathrm{r} 2$. The reduced of interest rate had encourage the higher investment in the product market to increase in the next iteration and so on.

Eventually, the total direct effect from the product market was reduced by the negative effect from the financial market and had left only the net effect to the economy. The economy had expanded only from the Y0 to Y2 not Y1, the amount of $\mathrm{Y} 0$ to $\mathrm{Y} 1$ is so called the total effect from the product market, but the amount of $\mathrm{Y} 1$ to $\mathrm{Y} 2$ is so called the negative effect from the financial market. Therefore, the economy had growth only from Y0 to Y2 level.

In factor market (step 6) due to the decreased of income or GDP, the entrepreneur was encourage to reduce their production. Therefore, the demand for labor had reduced from DL1 to DL2, employment also decreased from N1 to N2. Amount of wage paid to labor reduced from W1 to W2.

We can see that financial market is the lubricator for the economy and interest rate is the core transmission mechanism to absorb and reduced the size of total effect. But, if people in the economy and top management of the firm not stick into the right thing but do the wrong thing, the situation may be more serious as it had ever occurred in Thailand in 1997, and recently in the US in 2007.

From the overall seven models, we can see that when the problems occurred from the demand side it will finally affect to the supply side, especially on the labor market. Therefore, government in every country has to supervise and regulate for the efficient and effective economy for both the growth and stability of the economy. Government has to look after all of the expenditure of people and private sector, especially the financial market and the capital market for economic stability and economic growth.

\section{B. Cooperatives Economics}

In the opposite direction, the cooperatives economics concept had its philosophy of "not for profit organizations". Cooperatives will distribute all of theirs businesses surplus to their member in the form of patronage refund and dividend pay out. The patronage refund will depend on the member business volume with their cooperatives. Dividend pay out depend on the number of stock or capital, the cooperatives members buy to save their money as saving or investment.

1) Robert Owen (1771-1858)

This school of thought was originated from the time of Robert Owen, after the industrial revolution period in Britain. Owen belief in the value of cooperation rather than competition, he wrote a book named "A New View of Society: Essays on the Principle of the Formation of the Human Character (1813). He tries to propose his optimistic faith that education was capable of totally transforming self-interest into a concern for other. He tries to set up a self-supporting "village of cooperation" together with the donation of his own money to construct this formation. But, for many years of his activities the cooperatives concept is still walking in the route and in their walking street.
Cooperatives business was own by their members, create benefit to their members, and were control by their members. These three principles are: user owner, user benefit, and use control principle, (Cobia 1967) [4].

\section{2) Rochdale Pioneers}

In 1844, a group of 28 persons who are the founder of consumer cooperatives in England had originate the cooperatives regulation and finally, was conclude to be only 7 Rochdale Pioneers[5]' regulation of: voluntary and open membership; democratic member control; member economic participation; autonomy and independence; education, training and information; co-operation among cooperatives; and concern for community.

Business of the cooperatives organizations mostly depend on their board member administration, and their cooperatives' manager management approach. Thus the performance of the cooperatives organization and their efficiency depend mostly on their member involvement and participation to give guidance to their board member and co-ops managers during their yearly general meeting.

Since the cooperatives organizations were own by many owner. There are not interesting enough for general investor as same as the "Investor Owned Firms: IOF". However, cooperatives business organization has small effect or proportion to the GDP. Most people still prefer the capitalism, thus, how we can reduce the over consumption.

\section{Traditional Institutional Economics}

Institutional economics is about the role of the evolutionary process and the role of institutions in shaping economic behavior.

There were many prominent economists in this school of thought, such as Thorstein Veblen, and his follower Mitchell and Commons; J.M.Clark; and John Maurice (1844-1963). These schools proposed the concept of Institutional Economics. But most people have not used it to compromise and compensate for the social benefit.

Thorstein Veblen (1857-1929): is supposed to have founded the American school of "Institutional Economics". He proposed that institutional economics is about the study of the intellectual patterns, social and economics of the organization. His famous works were "Theory of the Leisure Class (1899)" and the "Theory of Business Enterprise (1904)".

Commons John Roger (1862-1945): is very famous on his three books: The "Distribution of Wealth (1983)", the "Legal Foundation of Capitalism (1924)", and "Institutional Economics (1934)". His works mostly related to the theory of collective action conceived as set of controls on conflicting private interests.

Mitchell Wesley Clair (1874-1948): is one of the three cofounded of the American Institutional economics school with Veblen and Commons. He written the "Business Cycles: The Problem and Its Setting (1927)", elaborated about the business cycle in the U.S.A.

J.M.Clark (1884-1963) had regarded himself as a follower of Veblen, Mitchell, and Commons as an institutionalist. He try to point out that most of the firms in the 
industry try to reach to be the monopoly, but he had the opposite view points and wrote a book "Theory of Monopolistic competition (1934). This book tries to assess the performance of industries and to design effective antitrust law to maintain competition. His most famous article is "Toward a concept of Workable Competition (1940)". His workable is mean perfect competition.

\section{New Institutional Economics (NIE)}

Many economists had proposed that the concepts and theories of economics both macroeconomic and microeco nomic are not wrong but the concept must be most suitable for only some issues during some period of times. As Paul Krugman [6] had proposed his opinion on the New York Times that "Economic policymakers systematically chose to hear only what they wanted to hear. What he named the "intellectual failure". For me, I quite agree with him for a long time of my self research study on the macroeconomic aspects. For example, the consequence of the concept of Classic, Neoclassic, Keynesian, and Post Keynesian macroeconomic policy which can solve the macroeconomic problems on one period and on one aspect, but not generally.

The economic governance is an integral part for maintaining the economic growth and stability (Ostrom and Williamson, 2009[7]). The Royal Swedish Academy of Sciences proposed that...Oliver Williamson (1971, 1975, and 1985) has argued that markets and firms should be seen as alternative governance structures, which differ in how they resolve conflicts of interest. The drawback of markets is that negotiations invite haggling and disagreement; in firms, these problems are smaller because conflicts can be resolved through the use of authority. The drawback of firms is that authority can be abused. In markets with many similar sellers and buyers, conflicts are usually tolerable since both sellers and buyers can find other trading partners in case of disagreement. One prediction of Williamson's theory is therefore that the greater their mutual dependence, the more likely people are to conduct their transactions inside the boundary of a firm.

The Royal Swedish Academy of Science continued to propose that...Elinor Ostrom (1990) has challenged the conventional wisdom that common property is poorly managed and should be completely privatized or regulated by central authorities. Ostrom concluded that the outcomes are often better than predicted by standards theories. The perspective of these theories was too static to capture the sophisticated institutions for decision making and rule enforcement that have emerged to handle conflicts of interest in user-managed common pools around the world. By turning to more recent theories that take dynamics into account, Ostrom found that some of the observed institutions could be well understood as equilibrium outcomes of repeated games. However, other rules and types of behavior are difficult to reconcile with this theory, at least under the common assumption that player are selfish materialists who only punish others when it is their own interest.
According to the literature review, a conceptual model was proposed to elaborate the factors to determine the economic sustainable development of every country as in Figure 2, and to avoid the economic disturbance, as posited in Figure 1. The model consists of one dependent variable and three independent variables. The dependent variable is the "economic mix" or "economic governance" which was consisted of the advantages from all three economic systems: Institutional profit, Firm optimizing profit, and cooperatives business surplus. The three group of each independent observe latent variables are: the first group is legal responsibility, social responsibility, and organizational responsibility. The second group is optimizing profit, capital accumulation, and private benefit but social cost. The third group is patronage refund, dividend payout, and retaining earning of the cooperatives organization, as posited in Figure 2.

\section{Research Methodology}

The study had come up with a testing of this synthesis. A questionnaire design was constructed belong to the measurement variables to ask the 45 respondent on their view points, they are agree with the variables in the model or not.

Multiple regression analysis was used to test the statistical reliability of the model. With the structural equation modeling (SEM), the study proposed the significant value of all measurement models and its structural model fit.

\section{Data Analysis and Results}

The questionnaire used in the primary survey had been tested of both content validity and it reliability. The study had tested all of the measurement score from the primary survey.

\section{A. Descriptive Statistics}

Mean and standard deviation of all respondent profile had been reported, three independent variables and one dependent variable were elaborated. All of the descriptive statistics are in the accepted and significant ranges.

\section{B. Inferential Statistics}

Overall variables were measured and rate on the ratio scale from 1-100, starting from 1-20 is least agree; $21-40$ is less agree; 41-60 is agree; 61-80 is mostly agree; and 81-100 is almost agree.

Inference statistics resulted with the significant of all correlation value, t-stat, F-stat, R2, adjust R2, beta or regression weight, and over all model fit statistics.

It implied that all the nine observed latent of the three independent variables are best explained the economic mix as posited in the final model and the economy will get their three level of benefits: institutional benefit/profit from the institutional economic activities, firm optimized benefit/profit from the capitalism economic system and cooperatives business surplus from the cooperatives economic system. 
Table 3: Measurement variables

\begin{tabular}{|c|c|c|}
\hline & Measurement & V. name \\
\hline X1-1 & $\begin{array}{l}\text { Institutional economic system concentrate on legal } \\
\text { responsibility, rule, norm, that will help society to } \\
\text { perform right, goodness, correction. }\end{array}$ & $\begin{array}{c}\text { Legal, } \\
\text { responsibility }\end{array}$ \\
\hline X1-2 & $\begin{array}{l}\text { Institutional economic system encourages social } \\
\text { responsibility for society. }\end{array}$ & $\begin{array}{c}\text { social } \\
\text { responsibility }\end{array}$ \\
\hline X1-3 & $\begin{array}{l}\text { Institutional economic encourage organization al } \\
\text { responsibility for our institution }\end{array}$ & $\begin{array}{l}\text { organizational } \\
\text { responsibility }\end{array}$ \\
\hline X2-1 & $\begin{array}{l}\text { CE system looks for optimizing profit not } \\
\text { maximizing profit }\end{array}$ & $\begin{array}{l}\text { Optimizing } \\
\text { profit }\end{array}$ \\
\hline X2-2 & $\begin{array}{l}\text { CE system too much concentrate on capital } \\
\text { accumulation }\end{array}$ & $\begin{array}{c}\text { Capital } \\
\text { accumulation }\end{array}$ \\
\hline $\mathrm{X} 2-3$ & $\begin{array}{l}\text { Invisible hand of CE must be holding society } \\
\text { together, it's not mean selfish to gain benefit as } \\
\text { much as possible }\end{array}$ & $\begin{array}{c}\text { Private } \\
\text { benefit } / \text { social } \\
\text { cost }\end{array}$ \\
\hline X3-1 & $\begin{array}{l}\text { CoE is a kind of business organization distribu ted } \\
\text { their business surplus to their member in the form } \\
\text { of patronage refund. }\end{array}$ & $\begin{array}{l}\text { Member } \\
\text { patronage } \\
\text { refund }\end{array}$ \\
\hline X3-2 & $\begin{array}{l}\text { CoE system is a kind of business organization } \\
\text { distributed their surplus to their member in the } \\
\text { form of dividend pay out. }\end{array}$ & $\begin{array}{c}\text { Member } \\
\text { dividend pay } \\
\text { out }\end{array}$ \\
\hline X3-3 & $\begin{array}{l}\text { Cooperatives organization collected only retain } \\
\text { earning to cover their business loss. }\end{array}$ & $\begin{array}{l}\text { Cooperatives } \\
\text { retain earning }\end{array}$ \\
\hline Y1-1 & $\begin{array}{l}\text { Sustainable economic development has to blend } \\
\text { economic responsibility, economic effi ciency, and } \\
\text { economics distribution together. }\end{array}$ & Economic mix \\
\hline
\end{tabular}

Notes: $\mathrm{CE}=$ Capitalism Economics, $\mathrm{IE}=$ Institutional Economics, $\mathrm{CoE}=\mathrm{Coops}$ Economics,

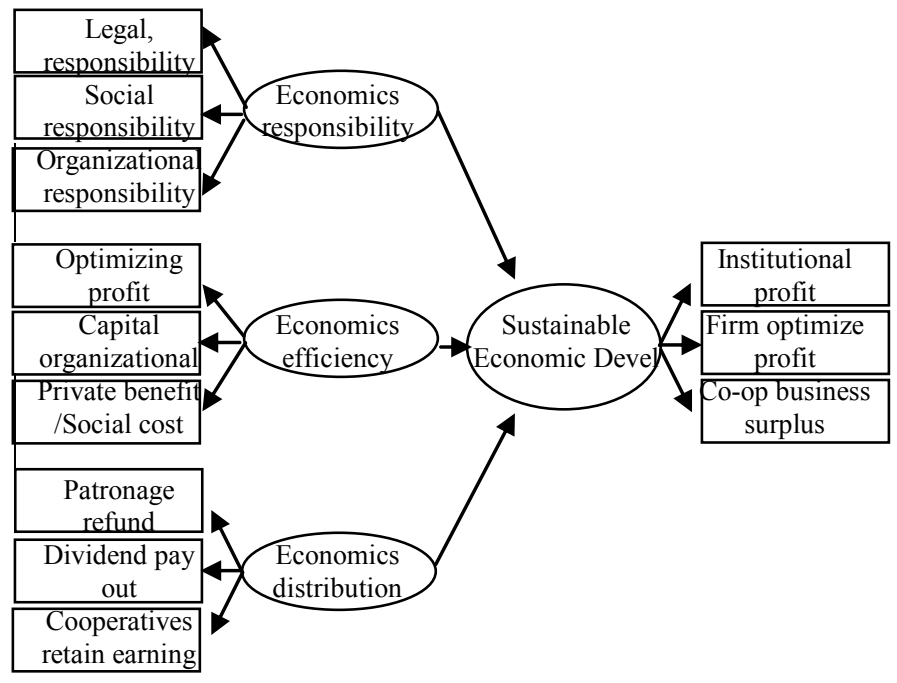

Figure 2: The Final Model
If we blend all of these three economic systems together, we will reach to the "economic mix" or "economic governance" which composed of "economic responsibility" from institutional economics, "economic efficiency" from capitalism economics, and "economic distribution" from the cooperatives economics. These three advantages should be more vigorously examined and blended into the policy making by the economists.

\section{Conclusion}

Sustainable economic development (SED) can be achieved by blending the advantages and get rid the disadvantages among capitalism economics system, institutionalism economics concept and cooperatives economics doctrine in to one economic mix. 45 economics academicians were invited to fill up the questionnaire. Respondents had agreed that to gain the SED, economic policy maker has to converge the "economics efficiency" from capitalism economics system, "economics responsibility" from institutionalism economics concepts and "economics distribution" from cooperatives economics doctrine into one economic mix.

\section{References}

[1] Mark Blaug, "Great economists before Keynes: An introduction to the lives \& works of one hundred great economists of the past," Wheatsheaf books 1986 ISBN 0-7450-0160-2.

[2] Mark Blaug, "Great economists before Keynes: An introduction to the lives \& works of one hundred great economists of the past," Wheatsheaf books 1986 ISBN 0-7450-0160-2.

[3] David Cobia " Cooperatives in Agriculture", New Jersey, Prentice Hall, Englewood Cliffs, 1989.

[4] Chanchai Petachprapunkul "Causes and Effects of the Over Demand in Product Market, Factor Market, and Financial Market Create Financial Crisis and Economic Downturn in Thailand, the U.S.A. and Greece", A Paper presented at the International Conference IRED, The University of Science and Technology of China, 2012 Conference Proceeding 2012.

[5] David Thompson, Cooperative Principle Then and Now, Cooperative Grocer, National Cooperative Grocer Association, Minnepolis 1994.

[6] Paul Krungman, "Economists fail on so many levels", The New York Time 2015.

[7] Ostrom and Williamson, Nobel Memorial Prize in Economic Sciences, The Royal Swedish Academy of Sciences, 2009. 